\title{
Michael Longley's Poetry of the Elements in Snow Water
}

\author{
Elisabeth Delattre \\ Université d'Artois
}

Copyright (c) 2011 by Elisabeth Delattre. This text may be archived and redistributed both in electronic form and in hard copy, provided that the author and journal are properly cited and no fee is charged for access.

Abstract. Nature has always played a major part in Michael Longley's poetry, for ecological reasons but also because of the feeling of empathy involved, as Snow Water published in 2004 testifies. This analysis will rely essentially on Gaston Bachelard's phenomenological approach which deals with the way human reverie on matter governs poetic writing as the sensitory experience of the world.

Key words. poetry, nature, elements, symbols, imagination

Resumen. La naturaleza ha jugado siempre un papel importante en la poesía de Michael Longley, por razones ecológicas pero también por el sentimiento de empatía que comporta, tal como pone de manifiesto el volumen Snow Water publicado en 2004. El siguiente análisis usará esencialmente la aproximación fenomenológica de Gaston Bachelard, que se basa en la manera en que la ensoñación humana en torno a la materia gobierna la escritura poética en tanto que experiencia sensorial del mundo.

Palabras clave. Poesía, naturaleza, elementos, símbolos, imaginación.

Le meilleur parti à prendre est donc de considérer toutes choses comme inconnues, et de se promener ou de s'étendre sous bois ou sur l'herbe, et de reprendre tout du début (Francis Ponge, Le Parti pris des choses).

Air, soil, water, fire - those are the words,

I myself am a word with them - my qualities interpenetrate with theirs (Walt Whitman, Leaves of Grass).

Defining Michael Longley’s poetry has always puzzled critics. Variously described as a 'Nature poet', a 'love poet', a 'neo-classical imitator and translator', or even a 'poet of the Troubles', Longley resists any single, defining characterizations. Yet most critics have stressed "his intent, minutely observant response to phenomena in the (specially natural) world about him”, an attitude which, according to Alan Peacock, "qualifies him, if anything, as a 'philosophical' poet - but one whose scepticism, intelligence and basic humility prevent insight and intuition from hardening into dogma and system" (Peacock 2000: xii). One of Longley's poet friends, Derek Mahon, has given a very apposite definition:

Longley is an Anglo-Irish poet who writes frequently about his native province [...]. $[\mathrm{M}]$ any of Longley's poems celebrate 'the 
family of living creatures' (birds, beasts and flowers, but people too). 'The lady of the house' (lover, wife, Muse) is a turf-scented locution Longley uses more than once ('home' too is a key-word); but it is those capricious moments that put the salt to the broth [...] preferring always to name the thing (Mahon 1996: 99).

This article aims at analysing the role of the four elements in the work published in 2004 by Michael Longley under the title Snow Water and reproduced two years later in Collected Poems, almost without any change, apart from a slight reordering and the suppression of the poem “Echoes” (Longley 2004: 12). Although this latest composition does not seem to have been as much praised as the previous collection, The Weather in Japan published four years before, the verse is at least as masterful, not only "simpler", or more "relaxed" - in the poet's own words -, but both deeper and more self-contained still. To quote what Longley wrote about Louis MacNeice, a fellow-poet he admires and whose selected poetry he edited some time ago: "His later poetry not only relishes idiom and clichés but probes their hidden codes. [...] MacNeice gets inside words" (Longley 1988, xix). For the composition of a poem proceeds from a reverence for the natural world but also from the choice of words, the rhythm of the sentences, akin to a religious experience in the way he "makes sense of the world", in other words, “an exploration”(Ni Anluain 2000: 125).

The French philosopher Gaston Bachelard published in the 1940s a series of books on the human imagination. His reflection was based on the distinction between the four elements borrowed from Aristotle: "every poetic must be endowed with components - as tenuous as they may be - of material essence" (Bachelard 1942: 5). ${ }^{1}$ This imaginary link with the elements is also kinetic, for the imagination, according to Bachelard, quoting Blake, is not a "state, it is the very human existence itself" (Bachelard 1943: 7-8). ${ }^{2}$ This article will rely on Bachelard's work in this analysis of the links between the poet's writing and the outside world.

1. "toute poétique doi[t] recevoir des composantes si faibles qu'elles soient - d'essence matérielle”

2. "un état, c’est l'existence humaine elle-même”

\section{Image and imagination}

Indeed, Longley's poetry is deeply rooted in the world in which he lives, the sense of location is paramount, but one cannot say that Belfast, where he has lived most of his life, or other places he has visited, play a major part, as he acknowledged a few years ago in an interview: "The absence of Belfast (or any city) from my poetry is a big gap, I agree" (Brown 2002: 92). Nevertheless, his writing is "conditioned" by his living in Belfast, all the more so as he has repeatedly deplored the deterioration of the natural environment. What counts for him is writing about what "moves" him and ecological matters are paramount in his philosophy of life as we can read in this statement: "Whether we live in a city or in the countryside, ultimately our lives depend on the plants and animals I write about" (Brown 2002: 92). His favourite place is the west of Ireland, county Mayo where he has spent countless periods of time, and which has inspired him most. That's why Michael Longley has characterized his own poetry in a somewhat subtle and elusive phenomenological way:

If I was to divide the four elements between my chums Mahon and Heaney, I would grant Mahon fire and air and Heaney water and earth. That's far too diagrammatic. Nevertheless there's a grain of truth in it. I would locate myself in between, free at the moment to choose between the four elements (Ni Anluain 2000 124).

In fact, Michael Longley's poetry contains elements which can be seen as belonging both to old and new knowledge, the ancient Greek and Latin literatures of course which have been usually analysed in detail by critics, but more specifically timeless aspects which are those of the world of nature, a poetry which might be defined as a kind of "Noah's Ark" (Brown 2002: 92), to quote Michael Longley’s own words. This original approach to his natural environment is reflected in the interpretation Longley gives of the events he witnesses, as for instance in the case of the "Indian boy". This poem might be seen as encapsulating the four elements mentioned above: "For me he means earthshine, earthlight / Faintly illuminating the crescent moon's / Unsunlit surface” (Longley 2004: 52). And the poet concludes with this vision: "his lips and his eyes / Are water glimmers and his headdress / 
An irradiation of white heron feathers" (Longley 2004: 52).

As Bachelard wrote in L'Air et les songes: "As far as the realm of the imaginary is concerned, everything that shines is a look" (Bachelard 1943: 210). ${ }^{3}$ This is the look the poet bestows on his environment, a look enhanced at times by the use of binoculars, of "binocular moments" shared with his beloved. Indeed, looking at the world, or rather gazing at it, can even be at times painful, as when the poet feels unable to count the number of swans: "I would count the swans but it hurts my eyes” (Longley 2004: 20).

It appears that the image has no intrinsic value, except through the network of meanings it unfolds. That's why Bachelard has concluded on the role of the imagination to open out onto the future: "to the function of the real, as instructed by the past, such as it is revealed by classical psychology, one must add a function of the unreal" (Bachelard 1957: 16). ${ }^{4}$ Thus the creative imagination is an organising dynamism and the poet has an essential role to play insofar as it is through poetry that we'll be able to rediscover our relation to the world. And Longley concludes his book on this line, when referring to his favourite beech tree: "I can imagine foliage on fire like that” (Longley 2004: 62). To quote again from Bachelard: "The tree is a flight reserve” (Bachelard 1943: 243). ${ }^{5}$ Furthermore, the tree helps the poet to " "carry the height', to go further than the canopies, to live an aerated, aerial life” (Bachelard 1943: 238). ${ }^{6}$ Of course the image of the tree is linked with or is often replaced by the image of the bird, more particularly that of the swan, "the whopperswan" but also much smaller birds, like the blue "tit", the "snipe", "the dipper", the "plover", the "barge" or the "god-wit" etc, which gives the opportunity for the poet to mock at times this show of knowledge: "What

3. “dans le règne de l'imaginaire, tout ce qui brille est un regard"

4. "A la fonction du réel, instruite par le passé, telle qu'elle est dégagée par la psychologie classique, il faut joindre une fonction de l'irréel'.

5. “L’arbre est une réserve d’envolée.”

6. 'L'arbre aide le poète à 'emporter la hauteur', à dépasser les cimes, à vivre d'une vie aérée, aérienne." amateur ornithologists we are!” (Longley 2004: 22). To refer to the bachelardian philosophy, the bird is seen as "free air personified" (Bachelard 1943: 94), and a bird's flight is meant as "transcending greatness” (Bachelard: 1943: 78). ${ }^{8}$ Of course there may be an allusion to William Butler Yeats, one of Longley's mentors: "Some moralist or mythological poet / Compares the solitary soul to a swan; / I am satisfied with that" (Yeats 1969: 233-4).

In such a synthetic reading the notion of theme will provide a useful and necessary starting point. The main themes that dominate Snow Water are wind and air, water and earth, with their corollaries which are the vegetal and animal world. This is summed up in a way in the poem "Above Dooaghtry", a poem Longley considers as his testament as he said in an interview in 2000:

This is the next little townland to Carrigskeewaun in County Mayo. There's a promontory there and standing on it I realized and this just happened last summer - that this is where I want my ashes to be buried. It's unbelievably windswept and mysterious. It's a holy place as far as I am concerned. There my ghost would be befriended by the otter, the mountain hare and the ravens. It's four five-line stanzas in length, and it's my will and testament, if you like” (Ni Anluain 2000: 133).

The frequency of the occurrences of the locality of Carrigskeewaun suggests that it is not only a place of vacation or inspiration but also a return to Mother Nature, even a sort of cocoon, a place where the poet wishes to rest eternally. Carrigskeewaun evokes images of rest, refuge, rootedness: "It is by dreaming of such intimacy that one dreams of the being's rest, a rest rooted, a rest that has an intensity and that is not only this exclusively external immobility which pervades every lifeless thing” (Bachelard 1948: 5). ${ }^{9}$ It will be possible reconstitute an imaginary universe proper to its

\footnotetext{
7. “Ainsi l’oiseau est l'air libre personnifié”

8. “transcendance de la grandeur”

9. “C'est en rêvant à cette intimité que l'on rêve au repos de l'être, à un repos enraciné, à un repos qui a une intensité et qui n'est pas seulement cette immobilité tout externe qui règne entre les choses inertes”.
} 
author but also ecumenical since the Bachelardian perspective will be counterbalanced by literary or biblical images and metaphors, which might be appear as caricatured in the poems "Woodsmoke" or "Helen's Monkey" dedicated to the sculptress Helen Denerley and what the poet calls her “metallic menagerie” (Longley 2004: 53). At the same time the symbol will constitute "a mediation of the Eternal into the temporal" (Durand 1964: 129), ${ }^{10}$ to quote Gilbert Durand in his book on the symbolic imagination. And Longley declares that since it is useless to believe in the after world, the present will constitute his own universe:

There's no such place as heaven, so let it be

The Carricknashinnagh shoal or Caher

Island where you honeymooned in a tent

Amid the pilgrim-fishermen's stations

(Longley 2004: 7).

One of the missions of the poet consists in building the bridge, or tracing the path, between Nature and the soul of man, or else in the poet's words: "Our souls are air. They hold us together.” (Longley 2004: 39) Objects and words, of which they are the signs, might at times seem to tend to disappear into the ultimate spiritual purpose; most of the time in Longley's poetry, things keep their rights, the concrete universe managing at times to get the best of the world of ideas. This is what he writes at the beginning of Snow Water, while referring humorously to his habit of "overdosing" on jasmine tea: "The wee transcendental mountain cottage / is where I continue painting almond / and plum blossoms into extreme old age" (Longley 2004 2). The poet devotes to the natural universe a bemused admiration, which might result in persuading him of the superiority of things over the derisory signs of the language and the difficulty of transcribing the world into verse. Here again the earth metaphor is used in the poem "An October sun": "Good poems are as comfortlessly constructed. / Each sod handled how many times" (Longley 2004: 8). Of course one might see a Whitmanesque touch in Longley's approach, yet Longley does not stress the indifference of the outside world to his own words and to his role as a poet. He prefers to write about what moves him, and the natural world is essential to his survival as he

10. "la médiation de l’Eternel dans le temporel.” has repeatedly said in various interviews:

Life is grass. We'd all starve without insects and flowers. Whether we live in a city or in the countryside, ultimately our lives depend on the plants and animals I write about. The writing of a poem is akin to what I imagine a religious experience might be. Poetry is the way I make sense of the world. It's an exploration" (Ni Anluain 2000: 125).

Being an elected object and the privileged activity for the motivating reverie, naming and nomination are for him an essential preoccupation. As Bachelard wrote in L'Air et les songes: "To mean something else and make one dream differently, such is the dual function of a literary image. Poetry does not express something which remains extraneous to it" (Bachelard 1943: 283) ${ }^{11}$ When arises the issue of a direct motivation of the language, and of the re-conquest of a natural language, in the last resort, there cannot be more primitive, more original words than the names of the elements. When the poet wonders whether there will be other poems in the future or whether death will come, he uses the image of the tree leaves and of the wind with the red glow of the sunset in the background:

Some of the poems depend

Peaceably like the brown leaves on a sheltered branch.

Others are hanging on through the equinoctial gales

To catch the westering sun's red declension

(Longley 2004: 62).

For the red colour, in contrast to the white of the snow, may be seen as a symbol of life, regeneration, as he wrote in a previous collection. It is intimately associated with the image of the fire: "fire is life; life is a fire" (Bachelard 1949, 79). ${ }^{12}$ In this extract from "Gorse Fires", the poet sees his life as a journey from one spring season to the next and associates the renewal of nature with that of his own:

I am travelling from one April to another.

It is the same train between the same embankments.

11. "Signifier autre chose et faire rêver autrement, telle est la double fonction de l'image littéraire. $\mathrm{La}$ poésie n'exprime pas quelque chose qui lui demeure étranger.”

12. "le feu, c'est la vie ; la vie est un feu" 
Gorse fires are smoking, but primroses burn

And celandines and white may and gorse

flowers (Longley 2006: 170).

Nomination appears as a narcissistic jubilation linked to infancy, a pleasure associated with a word that projects each of us into the realm of otherness, and joins it to death, while initiating its identity. In the poem entitled "Taxonomy" he refers to his practise in a humorous way: "I have fitted a hundred wing-glints into this one line” (Longley 2004, $50)$. The poet adheres to the romantic dream of a motivated language, as a mark of some nostalgia for a hypothetically primitive state of the language in which speech would have been what it was in a sort of innocent primitiveness, the source of a perfect adequacy with a paradise to re-conquer: "All of our eyes are broken rose windows” (Longley 2004: 45).

\section{Life and death}

Various critics have emphasized the botanical aspect of Longley's poetry, which is symbolic of philosophical reflections on life and death and man's place in the world, and this works as a sort of alibi to express "historical attitude or veiled biography" (Corcoran 1999: 162). In Neil Corcoran's words, "botany and psychology interpenetrate in a way that seems almost to constitute identity as evanescence; a lyric subjectivity discovers itself only in the act of witnessing or recording its own vanishing” (Corcoran 1999: 164). Yet it might be much less objective and impersonal than Corcoran seems to imply, all the more so as domestic experience is often the starting-point of Longley's poems. More significantly than the flowers, which symbolize the fragility and resilience of the natural world, of which mankind is emblematical, the images referring to birds and fish or rather mammals convey Longley's poetic world. The otter appears as emblematic of this hidden tragic fate:

The otters we haven't seen for years

(Although today we heard one whistling)

Shadows between dragonfly and elver

(Longley 2004: 10)

The symbolism of the otter, appearing and disappearing from the surface of the water, is linked with that of the moon, which bathes more than one poem in its white and cold glow, and is a precursor to death; hence the initiatory value of the otter, its role as a psycho pomp. Quite significantly in the Celtic legend, the symbolism of the otter is complementary to that of the dog: "Cuchulain starts the series of his exploits by killing a dog and he ends them, a few instants before dying, by killing an otter with a stone flung from a sling” (Chevalier \& Gheerbrant 1994, 584). ${ }^{13}$ The symbolism of the otter is also a recurrent element of the poet's images as we can read in a poem published in a previous collection: "I watched a dying otter gaze right through me / At the islands in Clew Bay, as though it were only / Between hovers and not too far from the holt” (Longley 2006: 167). Similarly, the omnipresence of the hare can be seen as linked with the moon, but also with the ancient goddess of Mother Earth, the symbolism of regenerating waters, vegetation and the endless renewal of life under all its forms. Water is probably the main element to which the poet constantly refers, as it is always what he can contemplate during his walks along the sea shores; it is both the symbol of life and death, "water is the matter by which Nature, amidst troubling reflections, prepares the mansions of the dream" (Bachelard 1942: 72). ${ }^{14}$ Such a world is emblematical of the great mystery where life renews itself through death. The spirit, which is diurnal, feels both envy and fear before such creatures which necessarily take on ambiguous significations: "are they stars fallen through the forest canopy?” (Longley 2004: 51) wonders the poet apropos a hare drawn by his daughter.

The music of the spheres which are the favourite haunt of birds can pervade the battlefields but most of the time it is the "pessimistic skin-and-bone aubade" of the robin (Longley 2004: 20) whose red breast echoes the cranberries or the red of the autumn sunset, another symbol of life and death, with death getting nearer and nearer to the dismay of the ageing "I" who, like Dr Faustus, would give anything to tarry the inevitable:

Not even you can make me love death, Odysseus: I'd far rather clean out ditches on starvation Wages for some nonentity of a smallholder Than lord it over the debilitated dead.

(Longley 2004: 43)

13. "Cuchulain commence la série de ses exploits en tuant un chien et il les termine, quelques instants avant de mourir, en tuant une loutre d'une pierre de fronde."

14. "l'eau est la matière où la Nature, en d'émouvants reflets, prépare les châteaux du rêve.” 
Last, but not least, the omnipresent image of the snow, in relation with that of the water, is a complex and manifold symbol, since it encompasses various fields that are dear to the poet. Of course it is humorously referred to in the making of tea at the beginning of the book, but it is water that is cold and even hostile. It can also appear as a symbol of spiritual life, but here the question remains unanswered in the poem "In Notre Dame": "Where is the holy water, the snow water for Job?” (Longley 2004: 45).

An analysis of the imaginary world of Michael Longley's poetry reflects a perpetually unresolved tension between two polar opposites, a precarious equilibrium achieved between past and present, good and bad, sorrow and happiness, regret and hope, nature and pollution. Domestic mundane life versus mortality and transience characterize Longley's poetry: "Sunlight strews leaf-shadows on the kitchen floor. / is it the beech tree or the basilplant or both," (Longley 2004: 57) asks the narrator in a poem entitled "Praxilla". The two main themes around which these aspects revolve are love and death, Eros and Thanatos. Hence the importance of place, roots necessary for the being to live and also to die, hence too the deep attachment to some locations, Mayo more particularly, but also Italy, or Belfast. Critics have noticed the "cellular" conception of his poems, the use of the "patchwork" metaphor as emblematic of the construction of art, leading to echoes and resonances from one poem to another, inter-relatedness and independence being the aim of Longley. This is shown in the poem entitled "Montale's Dove" in which the poet indirectly alludes to his own method:

He doesn't mention how the stained-glass windows

Make walls a momentary rainbow patchwork if

The sun is shining (Longley 2004: 47).

As in his previous works Longley's affinity with Japanese poetry, wood-engraving and porcelain, as containing ceremoniousness, delicacy but also some inherent violence, is seen as the only way of dealing with the unnameable, the atrocity of some events, such as the wars which rack various parts of the world and will continue to do so, whatever is said or done. The poem "Two Pheasants" appears as emblematic when the poet uses the accidental death of one of the birds:
I got the picture in no time in my wing-mirror As in a woodcut by Hokusai who highlighted The head for me, the white neck-ring and red wattles

The long coppery tail, the elegance and the pain

(Longley 2004: 23).

In short, all the themes alluded to in this article evince the measured, unresolved ambiguity of the poet's response to the outside world, a poet who would like to be seen as an "ecological" poet: "I trust I am more than a botaniser among the hedgerows. I would like to think of myself as an ecological poet, and therefore relevant right now when our most pressing problems are ecological - how we share the planet with the insects, the plants and other animals. I want my poetry to be like Noah’s Ark” (Brown 2000: 92).

\section{Conclusion}

At the end of this journey into the imaginary universe of Longley's poetry, a universe that includes diverse registers which overlap and complete each other it appears that there is an attempt on the part of the writer to build a new reality drawn from the metaphorical network that underlines the poetic discourse. The tissue of life becomes that of the writing and viceversa, and we attend to the creation of a kind of web which does not aim to show a referent that does not exist, but to create an unreal more real by means of a metaphorical network. Thanks to a structure that superimposes images, the imagination of the poet is joined at the term of its journey through the unreal to a reality it has itself created, as Maurice Blanchot has explained in L'Entretien infini: “Image, imaginary, imagination do not only refer to a capacity for interior phantasms, but to an entrance into the very reality of the unreal [...] and at the same time to the re-creating and renewing measure of the real that is the opening of unreality" (Blanchot 1969: 476). ${ }^{15} \mathrm{I}$ would like to end on two lines from a poem published as early as 1969, which epitomize Michael Longley's deepest wish and constant quest as a poet of the elements. This poem which is dedicated to Seamus Heaney bears the

15. “image, imaginaire, imagination ne désignent pas seulement l'aptitude aux phantasmes intérieurs, mais l'accès à la réalité propre de l'irréel [...] et en même temps la mesure recréante et renouvelante du réel qu'est l'ouverture de l'irréalité.” 
very significant title of "A Personal Statement”:

My brain-child, help me find my own way back

To fire, air, water, earth (Longley 2006: 11).

\section{Works Cited}

Bachelard, Gaston. 1942. L'Eau et les rêves. Paris: Corti. . 1943. L'Air et les songes. Paris: Corti. . 1948. La Terre et les rêveries du repos. Paris: Cortis. . 1949. La Psychanalyse du feu. Paris: Gallimard. 1957. Poétique de l'espace. Paris: P.U. de France.

Blanchot, Maurice. 1969. L'Entretien infini. Paris: Gallimard.

Brown, John (ed.). 2002. In the Chair: Interviews with Poets from the North of Ireland. The Cliffs of Moher: Salmon Publishing.

Chevalier, Jean \& Gheerbant, Alain. 1994. Dictionnaire des symboles. Paris : Robert Laffont.

Corcoran, Neil. 1999. Poets of Modern Ireland, text, context, intertext. Cardiff: University of Wales Press.

Curtis, Tony (ed.). 1996. “A Tongue at Play”, in How Poets Work. Bridgen: Seren Books, pp. 113-4.

Durand, Gilbert. 1964. L'Imagination symbolique. Paris: P.U.F..

Longley, Michael (ed.). 1988. Louis Macneice. Selected Poems. London: Faber \& Faber.

Longley, Michael. 20004. Snow Water. London: Cape 2004.

. Collected Poems. 2006. London: Cape.

Brown, Terence (ed.). 1996. Derek Mahon. Journalism. Loughcrew: Gallery Books.

McDonald, Peter. 1988-9. “An Interview with Michael Longley”, Thumbscrew, nº12, Winter, online edition, http://www.poetrymagazines.org.uk/.

Ni Anluain, Cliodhna (ed.). 2000. Reading the Future, Irish Writers in Conversation with Mike Murphy. Dublin: The Lilliput Press.

Peacock, Alan \& Devine, Kathleen (eds.). 2000. The Poetry of Michael Longley. Ulster Editions \& Monographs. Gerrards Cross: Colin Smythe.

Yeats, W.B. 1969. Collected Poems. London: Macmillan.

Received 19 December 2010 Last version 5 January 2011

Elisabeth Delattre holds a PhD on the work of the Anglo-Irish novelist, J.G.Farrell. She has published a number of articles in Etudes Irlandaises and various other journals and collective works. She specialises in contemporary Irish literature, including Derek Mahon, Ciaran Carson, J.G.Farrell and Michael Longley. She teaches at the Université d'Artois in Arras, France, and is also a research associate with the Centre for Irish Studies at the University of Lille. 